\title{
Assessment of chromium induced alterations on gut bacterial population of $E$. eugeniae
}

\author{
Shefali* \\ Department of Zoology and Aquaculture, CCS Haryana Agricultural University, Hisar \\ (Haryana), India \\ Jyoti Yadav \\ Department of Zoology and Aquaculture, CCS Haryana Agricultural University, Hisar \\ (Haryana), India \\ R. K. Gupta \\ Department of Zoology and Aquaculture, CCS Haryana Agricultural University, Hisar \\ (Haryana), India \\ *Corresponding author. E-mail: shefaligulliya@gmail.com

\begin{abstract}
The aim of the present study was to enumerate the diversity of gut bacterial population of epigeic earthworm species, E. eugeniae exposed to heavy metal. Adult earthworms were treated with three different doses $(0.06 \%, 0.13 \%$ and $0.19 \% \mathrm{w} / \mathrm{v})$ of potassium dichromate $\left(\mathrm{K}_{2} \mathrm{Cr}_{2} \mathrm{O}_{7}\right)$ for this purpose. The gut samples were serially diluted and inoculated in seven distinct media viz. Jensen's media, King'smedium B base, Burk's media, Yeast Mannitol Agar media, Vogel- Johnson agar base media, Luria Bertani Broth Miller and Nutrient agar media. Dose dependent decrease in bacterial population was observed in treated worms when compared with control. Maximum percent change $(62.59 \%)$ in bacterial population was observed in Burk's media when exposed to $0.19 \%$ chromium. The results revealed that chromium alters the microbial population present in gut of earthworms. Therefore, changes in earthworms' gut microbial community due to soil management practices can also be used as markers of soil fertility and quality.
\end{abstract}

Keywords: Bacterial population, chromium, Earthworm, Media

\section{Article Info}

DOI:10.31018/jans.v11i1.1974 Received: December 26, 2018 Revised: February 1, 2019 Accepted: February 7, 2019

\section{How to Cite}

Shefali, et al. (2019).

Assessment of chromium induced alterations on gut bacterial population of E. eugeniae. Journal of Applied and Natural Science, 11(1): 94 - 96

\section{INTRODUCTION}

Earthworms are present in many agro-ecosystems and well known as the voracious feeders of all organic wastes and reduce their volume by about $50 \%$. They expel the digested material in the form of castings which is rich in nutrients and helps in amending the physico-chemical and biological properties of soil (Cikutovic, 1993). With the predominance of a solid phase constituted of soil organic matter, soil is a complicated heterogeneous system having plants, microbes and faunas (Nannipieri and Badalucco, 2003). Earthworms are the vital soil invertebrates having an association with soil microorganisms which ranges from commensalism to species-specific mutualism (Sampedro and Whalen, 2007, Esakkiammal and Lakshmibai, 2013). Additionally, soil contains a large diversity of microorganisms (Torsviket al., 2002). The potentially important environmental pollutants due to their trends to accumulate on vital organs of humans and animals are heavy metals $\mathrm{Pb}, \mathrm{Cd}$, As and $\mathrm{Cr}$ (Garbisu and Alkorta, 2003, Verma and Dwivedi, 2013, Shefali et al., 2018). Chromium is released into the environment by a number of processes such as steel manufacturing, pulp processing, wood preservation, leather tanning, metal plating, metal cleaning and processing and alloy formation, mostly with-out proper treatment. As a consequence, elevated concentrations of chromium become a major threat to the environment (Rangasamyet al., 2013).The impact of heavy metals in soils on earthworms and their bioaccumulation has been the subject of numerous examinations for a long time (e.g. Bouche, 1984; Morgan and Morgan, 1999; Kennetteet al., 2002; Ravindran et al., 2015; Dutta and Dutta, 2016), therefore, heavy metals enter the body of the worm and may cause alterations in gut bacterial population. The aim of the present examination was to investigate the impact of chromium on the gut bacterial population of earthworms.

\section{MATERIALS AND METHODS}

Seven media viz. Jensen media, King's media, Vogel- Johnson agar base media, Burk's media, Luria Bertani media, Nutrient agar media and Yeast Mannitol Agar media were prepared by using distilled water. The media was sterilized by autoclaving at $15 \mathrm{psi} / 121^{\circ} \mathrm{C}$ pressure/temperature 
for 20 minutes. The media was allowed to cool and poured in sterilized petri plates and after solidification, these plates were kept inverted (Martin, 1950). Different concentrations of Potassium dichromate $\left(\mathrm{K}_{2} \mathrm{Cr}_{2} \mathrm{O}_{7}\right)$ were prepared and healthy, clitellated adults of $E$. eugeniae (500700mg) were exposed on Whatman no. 1 filter paper coated flat bottom glass vials according to the Table 1. After one hour the worms were dissected and the guts was used for preparation of dilution of $10^{-4}$. $0.1 \mathrm{ml}$ aliquots of diluted bacterial samples were taken after shaking and were inoculated on different petri plates having different medium each by pour plate technique and the inoculums were spread with the help of spreader on different petri plates having different medium. The plates were incubated in B.O.D for 72 hours at $28 \pm 2^{\circ} \mathrm{Cin}$ inverted position and thereafter, the colonies were counted carefully and expressed as CFU $\times 10^{4} \mathrm{ml}^{-1}$. The experiment was laid out with three replicates using Completely Randomized Factorial Block Design. The critical difference was worked out at $5 \%(0.05)$ probability levels using Software 'OPSTAT', developed at the Computer Centre, College of Basic Sciences and Humanities, CCS Haryana Agricultural University, Hisar.

\section{RESULTS AND DISCUSSION}

Significantly lower gut bacterial population was observed in worms exposed to T4 cultured on all media compared to control. All the treatments also showed significantly lower gut bacterial population as compared with each other with an exception of worms exposed to T2 and T3 cultured on NA media. Dose and time dependent decrease in gut bacterial population was observed in all treatments in various media (Fig. 1). Maximum percent change $(62.59 \%)$ in bacterial population was observed in Burk's media when exposed to T4 (Fig. 2). Flack and Hartenstein 1984 and Ranganathan and Parthasarathi, 1999 reported earthworms as microbivorous. Earthworms' diet constitutes microorganisms as important nutritional component (Edwards and Bohlen, 1996) which is essential for their growth, development and reproduction (Parthasarathi and Ranganathan, 2000). The total viable microbial count observed in the gut of $E$. Eugeniae exposed to chromium is detailed in Figure1. The maximum bacterial counts were statistically higher in control sample of Nutrient agar media(176.00 \pm 2.31) followed by Yeast Mannitol

Table 1. Description of doses given to the earthworm during experiment.

\begin{tabular}{|c|c|c|c|}
\hline S. N. & Treatment & Description & \\
\hline 1. & T1 & $\begin{array}{l}\text { Control(Distilled water, } \\
\text { Chromium) }\end{array}$ & No \\
\hline 2. & T2 & Chromium $0.06 \%$ & \\
\hline 3. & T3 & Chromium $0.13 \%$ & \\
\hline 4. & T4 & Chromium $0.19 \%$ & \\
\hline
\end{tabular}

Agar media(165.33 \pm 4.48 )as compared to those in gut of treated worms. The maximum decrease in the bacterial population was noticed in Jensen's media $(64.01 \%)$ followed by Vogel- Johnson agar base media(44.52\%), exposed to T4 as compared to control. However, when cultured on Luria Bertani Broth Miller, significantly lower viable counts $(37.33 \pm 2.73)$ were observed in gut of worms exposed to T2, T3 and T4 as compared to each other and control. Similarly significant reduction in total bacterial count in worms exposed to arsenic was observed in comparison to control when cultured on King'smedium B base, Burk's media, Yeast Mannitol Agar media and Nutrient agar media. Microbial population and humic acid content in earthworm casts represents a direct correlation with the increase in microbial population, there is an increase of microbial activity and humic acid content (Parthasarathi et al., 2007; Sonia et al., 2016). Being a part of soil fauna, worms are easily exposed to soil pollutants either due to ingestion or due to contact with skin (Dallinger and Rainbow, 1993). Earthworms are accounted to have relationship with such free living soil microbes and constitute drilosphere, heavy metals at higher concentrations alters the survival of bacterial communities (Ravindran et al., 2015). Esakkiammal and Lakshmibai, 2013 reported that the bacterial population was more in mid gut than foregut and hindgut region and the results demonstrated that the organic substrates used could initiate the prolifera-

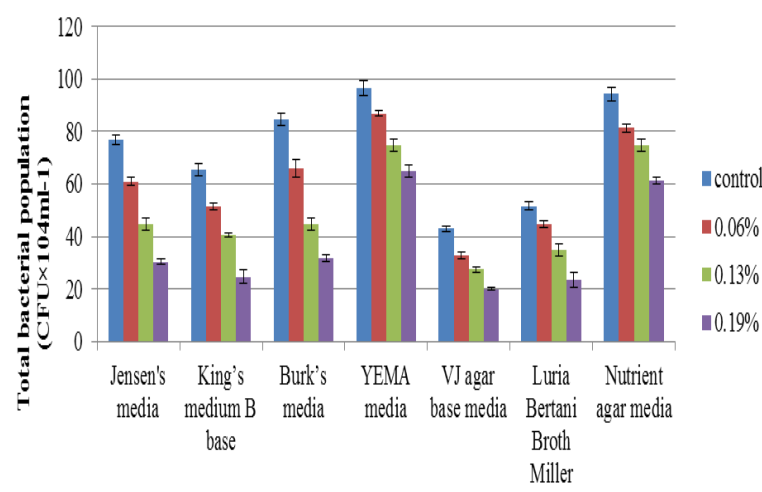

Fig. 1. Bacterial count in E. eugeniae gut exposed to chromium.



Fig. 2. Percent change in bacterial population of $E$. eugeniae exposed to T4. 
tion of micro-organisms. However, each one of these examinations was confined to one part of earthworm-microbe relationship or proliferation of microbes in gut and casts. They together mineralize and humifies the organic matter. Thus, from the investigation it is inferred that chromium at higher concentration alters the survival of bacterial communities.

\section{Conclusion}

In conclusion bacteria were found to have symbiotic relationship with earthworms' gut which helps in mineralization and decomposition during vermicomposting. Worm casts also act as microsite for microbes which results in having enormous number of bacterial population on substrate. Heavy metals have reported incidences of toxicity in earthworms and the present study shows that chromium at higher concentrations alters the survival of the bacterial communities.

\section{ACKNOWLEDGEMENTS}

We thank to the authorities of Department of Zoology to make available the facilities and timely help required for carrying out the research program.

\section{REFERENCES}

1. Bouche, M.(1984). Ecotoxicologie des lombriciens. 2. Surveillance de la contamination des milieux.OecologiaApplicata, 5: 291-301.

2. Cikutovic, M. A., Fitzpatrick, L. C., Venables, B. J. and Goven, A. J.(1993). Sperm count in earthworms (Lumbricusterrestries) as a biomarker for environmental toxicology: effects of cadmium and chlordane. Environmental Pollution, 81: 123-125.

3. Dallinger, R. and Rainbow, P.S. (1993). Ecotoxicology of Metals in Terrestrial Invertebrates. Lewis Publishers: London.

4. Dutta, A. and Dutta, H.(2016). Some insights on the effect of pesticides on earthworms. International Research Journal of Environment Sciences, 5: 61-66.

5. Edwards, C. A. and Bohlen, P. J.(1996). Biology and Ecology of earthworms. Chapman and Hall, London.

6. Esakkiammal, B. and Lakshmibai, L.(2013). Enumeration of bacterial population in the gut region of Eudriluseugeniae. International Journal of Current Microbiology and Applied Sciences, 2(5): 267-270.

7. Flack, F. M. and Hartenstein, R.(1984). Growth of the earthworm Eisenia fetidaon microorganisms and cellulose. Soil Biology and Biochemistry, 16:491-495

8. Garbisu, C. and Alkorta, I.(2003). Basic concepts on heavy metal soil bioremediation. The European Journal of Mineral Processing and Environmental Protection, 3: 58-66.
9. Kennette, D., Hendershot, W., Tomlin, A. and Sauve, S.(2002). Uptake of trace metals by the earthworm LumbricusterrestrisL. in urban contaminated soils. Applied Soil Ecology, 19: 191-198.

10.Martin, J.P. (1950). Use of acid rose Bengal and streptomycin in plate method for estimating soil fungi. Soil Science, 69: 215-232.

11.Morgan, J. E. and Morgan, A. J.(1999). The accumulation of metals $(\mathrm{Cd}, \mathrm{Cu}, \mathrm{Pb}, \mathrm{Zn}$ and $\mathrm{Ca})$ by two ecologically contrasting earthworm species (LumbricusrubellusandAporrectodeacaliginosa): implications for ecotoxicological testing. Applied Soil Ecology, 13: 9-20.

12.Nannipieri, P. and Badalucco, L.(2003). Handbook of processes and modelling in the soil-plant system. Biological processes. In: Benbi DK, Niedere R (eds) Haworth, Binghamton, N.Y. pp 57-82.

13.Parthasarathi, K. and Ranganathan. L S.(2000). Influence of pressmud on the development of the ovary, oogenesis and the neurosecretory cells of the earthworm, Eudriluseugeniae(Kinberg). African Zoology, 35 (2): 281-286.

14.Parthasarathi, K., Ranganathan, L.S., Anandi, V. and Zeyer, J.(2007). Diversity of microflora in the gut and casts of tropical composting earthworms reared on different substrates.Journal of Environmental Biology,28(1): 87-97.

15.Ranganathan, L. S. and Parthasarathi, K.(1999). Precocious development of LampitomauritiiandEudriluseugeniaereared in pressmud.Pedobiologia, 43: 904-908.

16.Rangasamy, S., Alagirisamy, B., Purushothaman, G. and Santiago, M.(2013). Effect of vermicompost on biotransformation and bioavailability of hexavalent chromium in soil. IOSR Journal of Agriculture and Veterinary Science,5(3): 34-40.

17.Ravindran, B., Contreras-Ramos, S. M. and Sekaran, G. (2015). Changes in earthworm gut associated enzymes and microbial diversity on the treatment of fermented tannery waste using epigeic earthworm Eudriluseugenia. Ecological Engineering, 74:394-401

18.Sampedro, L. and Whalen, J. K.(2007). Changes in the fatty acid profiles through the digestive tract of the earthworm Lumbricusterrestris. Applied Soil Ecology,35: 226-236.

19.Shefali., Gupta, R. K. and Yadav, J.(2018). Reproductive parameters as assessment tools for arsenic and chromium inducedtoxicity in Eudriluseugeniae. Indian Journal of Agricultural Research,52(6):676-680

20.Sonia, V., Felix, S. and Antony, C.(2016). Comparative study of growth and reproduction of earthworm Eudriluseugeniae in different organic substrate. International Journal of Applied Sciences, 4: 61-68.

21.Torsvik, V. and Ovreas, L.(2002). Microbial diversity and function in soil: from genes to ecosystems. Current Opinion in Microbiology, 5: 240-245. 